Volume 6 Issue 2, 2020

P-ISSN : 2460-5697, E-ISSN : 2655-2906

Website: https://www.jurnal-umbuton.ac.id/index.php/Pencerah

\title{
The Kinds of Translation Error Made by the Students in Writing Abstract of the Theses and Dissertations
}

\section{Munawir}

Email: munawir@iainpare.ac.id

\begin{abstract}
This research aims to find the kinds of translation error made in writing abstract of theses and dissertations. This research used descriptive quantitative method to analyze and expose the errors of abstracts of theses and dissertations. The data of this research was the abstracts of theses and dissertations of universities in Makassar. It took 61 abstracts of theses and dissertations from different universities. The abstracts is analyzed by using error analysis technique. The result of this research concluded that the abstracts are found various errors. Errors in the kinds of translation were Omission - Deviation - Modification - Addition - and the least is Inversion. The result of this research provides a new information about translation to the students especially to non-English students, and motivate them to translate the abstract well.
\end{abstract}

Keywords: Abstract; Translation Error, Writing

\begin{abstract}
Abstrak
Penelitian ini bertujuan untuk menemukan jenis-jenis kesalahan yang dibuat dalam menulis abstrak tesis dan disertasi. Penelitian ini menggunakan metode kusntitatif deskriptif untuk menganalisi dan mengungkapkan kesalahan abstrak tesis dan disertasi. Data penelitian ini adalah abstrak tesis dan disertasi universitas di Makassar. Data sebanyak 61 tesis dan disertasi dari universitas yang berbeda. Abstrak dianalisis menggunakan teknik analisis kesalahan. Hasil penelitian ini menyimpulkan bahwa abstrak ditemukan berbagai kesalahan. Kesalahan dalam translasi adalah Omission - Deviation Modification - Addition - dan Inversion. Hasil penelitian ini menyediakan informasi baru terkait translasi ke mahasiswa khususnya mahasiswa non-bahasa inggris dan memotivasi mereka untuk membuat asbtrak dengan baik.
\end{abstract}

Kata kunci: Abstrak, Kesalahan Translasi, Penulisan

\footnotetext{
${ }^{1}$ English Education Departement, IAIN Parepare, Indonesia
} 


\section{INTRODUCTION}

Talking about language skill, the researcher normally refers to listening, speaking, reading, and writing. However, there is another skill in learning foreign language that is very important, and cannot be neglected, namely translation. Translation is a bridge of communication among different people with different language and culture. A true translation facilitates the reader to get good and true information while a false translation will mislead the reader and out of the content of the writing.

Translation has a crucial role in aiding understanding of an increasingly fragmentary world (Basnet, 1991). Without translation, people of across cultural background cannot build a communication well. Communication can be the daily communication or communication in certain purposes such as educational communication, political communication, or trading communication. In regards to this statement, Jumpelt asserts that the twentieth century is the age of translation (Mehta, 2010). It shows how significant the translation is.

The final step of writing a thesis or dissertation is writing the abstract. In this case, in recent years, students of post graduate program are required to write thesis and dissertation abstracts in English although they are not English department students, because the theses and dissertation will be read not only by the native students but also by the foreign students that exactly do not understand Indonesian language well. The post graduate program has given English as subject in their study. However, not all of post graduate students have good skills in English particularly in doing translation. Therefore, some translation errors still occurred. Two problems were found based on the background. First was kinds of translation errors found in abstracts of theses and dissertations and second was the dominant kind of translation errors found in abstracts of theses and dissertations.

Translation is defined by many experts through various ways in different approaches and theoretical backgrounds. So, the different researcher will define translation in the different ways. There are some definitions of translation which is taken from many sources, Owen (1998) states that translation is the transfer of the meaning of a text (which maybe a word or a book) from one language to another for a new readership. Newmark (1981) asserts that translation is a capability to transfer the text (written message) from a language into written message of another language. Here, Newmark focuses on only one skill, he limits the definition only in the scope of written skill. Brislin (1976) states that translation is a think referring to the transferring of thoughts and ideas from the source language to the target language both written or oral form. Bell (1991) states translation is re expressing an idea from the source language to another language (target language) by constantly maintaining semantic and stylistic equivalence. In the other word, translation is not only transferring the word of the text to the target language but also transferring the essence of the text. Fundamentally, the statements about translation above have the same purpose, it can be concluded that translation is a way to transfer messages, ideas, and information from a language (source language) to the other language (target language) by maintaining the essence of the text. The core point of translation is the translator must preserve the purpose of the message of the original text. Translation is a process of transferring message. Because translation is a process, so, for getting the good ways and nice results in doing translation, there are some steps and proceduresof translationthat have to be understood by the translator. The process oftranslation is anactivitydone by thetranslator in transferring the meaning 
from thesource language tothe target language nicely. Nida \& Taber (1982) point out three steps or phases of a translation process. The steps can be found as follows.

1) Analysis. In this step, a translator is advised to analyze or understand the text/message before starting to transfer or translate it into the target language.

2) Transfer. After analyzing and understanding the text/message of the source language, the translator transfers the message from the source language into the target language.

3) Restructuring. After transferring the text, the translator should reconstruct or restructure the transferred text for getting an acceptable target language construction and meaning.

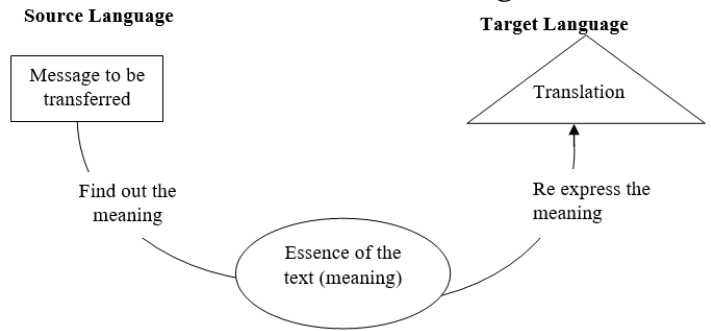

Figure 1. Translation process by Larson (Larson, 1984)

Larson explains that in translating a text, the translator's purpose is an idiomatic translation which makes some efforts to communicate the meaning or purpose of the source language into the naturalness word or sentence of the target language (Grahaprilwana, 2009). Furthermore, she states that translation is focused on a study of lexicon, structure and grammar, environment situation of communication, and cultural condition of the source language text, which is analyzed in order to determine its meaning and to facilitate in transferring. The diagram of Larson's translation process can be seen in Figure 1.

The forms of the frame of the text 'message to be translated' and 'translation' are shown by the different forms between square and triangle. It asserts that in translating a text, Larson suggests that the forms of the source language (SL) maybe changed into appropriate forms of the receptor language in order to achieve the essence of the meaning of source language (idiomatic translation). The word abstracts taken from the Latin that is abstractsum, which means a concise form of a longer piece of a writing. Abstract is a brief comprehensive summary of the contents of a writing article or project that enables the reader to observe the contents of the writing quickly (Zoltan \& Hipp, 2005).

This research aims to find the kinds of translation error made in writing abstract of theses and dissertations consisting of inversion, addition, omission, deviation, and modification.

\section{METHOD}

In this research, the researcher used descriptive method to analyze and expose the errors of abstracts of theses and dissertations for answering the questions emphasized in the research questions. Descriptive method is applied by explaining, analyzing, and classifying something through some techniques, survey, interview, questionnaire, and test (Fraenkell \& Wallen, 1993).

\section{Subject of the Research}

This research applied purposive sampling in getting the data because not all of the theses and dissertation is provided manually in the library. The data of this research was the abstracts of theses and dissertations of universities in Makassar. As stated by Roscoe (Sekaran, 2006) that the size of sample at least 30 and less than 500 are common size used by scholars. Because of the limitation of prepared abstract of theses and dissertations prepared in the library that had been translated into English, so, the researcher only chose 61 abstracts of 
theses and dissertations from different universities. The chosen abstracts then analyzed by using error analysis technique.

\section{Data Collection Procedure}

The researcher came to the library of post graduate program of Universities in Makassar and gather 61 (sixty-one) theses and dissertations to get abstracts for each thesis and dissertation purposely. After collecting the data, the abstracts were analyzed through error analysis technique.

\section{Data Analysis Technique}

Before analyzing the data, the relevant data had to be selected, signed, and moved into the available data sheets. The data sheets used to simplify the analysis process and to avoid overlapping of the kinds of error analysis. The example of data sheet utilized in this research can be seen in Table 1 (Mansyur, 2006).

Table 1. Data Sheet

\begin{tabular}{ll}
\hline \multicolumn{1}{c}{ Key } & \multicolumn{1}{c}{ Data } \\
\hline $\begin{array}{l}\text { Source } \\
\text { sentence }\end{array}$ & $\begin{array}{l}\text { Permasalahan yang } \\
\text { dibahas di dalam } \\
\text { penelitian ini } \\
\text { menyangkut kesantunan } \\
\text { bahasa guru terhadap } \\
\text { siswa. }\end{array}$ \\
$\begin{array}{l}\text { Translation } \\
\text { key }\end{array}$ & $\begin{array}{l}\text { The problem of this } \\
\text { research is about the } \\
\text { suavity of the teacher's } \\
\text { language to the students. } \\
\text { Pranslation } \\
\text { abstract }\end{array}$ \\
& $\begin{array}{l}\text { Problem studied concern } \\
\text { on the teacher's language } \\
\text { suavity to the students. }\end{array}$ \\
\hline
\end{tabular}

The technique used to analyze the data was Error analysis techniques. In this research, there are four steps in analyzing the data and they are can be found below:

a. Descriptive method used to Examine or Analyze the translation error of abstracts. For the purpose, the researcher applied content analysis by choosing the sentence as the main target of the analysis. This analysis done based on the kinds of error (inversion, addition, omission, deviation, and modification).

b. Classifying the translation errors into five kinds of errors.

c. Calculating the total number and percentage of each kind and source of errors to find out the amount of each kind errors by using the following formula:

$$
\mathrm{P}=\frac{\mathrm{F}}{\mathrm{N}} \times 100 \%
$$

P: Number of percentages

F: Frequency of kinds and sources of errors in translation

$\mathrm{N}$ : Number of whole errors in abstracts.

To illustrate better of how the procedure takes place, the data analysis grid given below. Data Analysis Grid of each abstract.

Table 2. Data Analysis Grid

\begin{tabular}{|c|c|c|c|c|}
\hline No. & Source sentence & $\begin{array}{l}\text { Student's } \\
\text { Translation }\end{array}$ & Translation key & $\begin{array}{c}\text { Kinds } \\
\text { of Error } \\
1 / 2 / 3 / 4 / 5\end{array}$ \\
\hline 1. & $\begin{array}{l}\text { Permasalahan yang } \\
\text { dibahas di dalam } \\
\text { penelitian ini } \\
\text { menyangkut } \\
\text { kesantunan bahasa } \\
\text { guru terhadap } \\
\text { siswa. }\end{array}$ & $\begin{array}{l}\text { Problem studied } \\
\text { concern on the } \\
\text { teacher's } \\
\text { language suavity } \\
\text { to the students. }\end{array}$ & $\begin{array}{l}\text { The problem of } \\
\text { this research is } \\
\text { about the } \\
\text { suavity of the } \\
\text { teacher's } \\
\text { language to the } \\
\text { students. }\end{array}$ & 4 \\
\hline
\end{tabular}

Note. Kinds of error: 1= Inversion. 2= Addition. 3= Omission. 4=Deviation. 5= Modification

The data analysis grid above was used to analyze and classify the data based on the kinds of error in translation. The data above showed deviation error because the English language translation has a vague translation and it can make the reader difficult to comprehend the meaning of that sentence even make a wrong interpretation.

\section{$3 . \quad$ RESULT \\ DISCUSSION}

\subsection{Finding}


All of the data put in this finding was collected from students' translation of abstracts of theses and dissertations. The translations of the abstracts were identified and classified based on the kinds of errors in translation. The grade of errors was shown within this writing for facilitating the reader in understanding the data well. The detail elaboration of the data can be found as follows:

In English sentence, the classifying of word class has crucial role in transferring the meaning because such word has same form but different word class and meaning. The student made an unclear translation because most words and phrase placed wrong position such us the words "to learning". In English rule, "to" have to be followed by bare infinitive while the real word of "learning" is learn + ing so it is not bare infinitive. The other wrong is the words "to increase learn" because "increase" and "learn" are verb while in this case verb cannot be followed by verb (bare infinitive) so it is wrong. For getting good translation, the translator should have known about word classes and know when he/she should put verb, noun, adjective or the other class of word.

\section{The Frequency and Percentage of Error}

1) The frequency and percentage of kinds of errors

In this research, the researcher analyzed 61 abstracts of theses and dissertations of universities in Makassar and found 165 kinds of translation errors. The least of the kinds of error was inversion of meaning with 10 errors $(6.0 \%)$, the next was addition of meaning with 14 errors $(8.4 \%)$, modification of meaning with 29 errors (17.5\%), deviation of meaning with 40 errors $(24.2 \%)$, and the most was omission of meaning with 72 errors $(43.6 \%)$.

Table 3. Frequency and Percentage of Kinds of Error

\begin{tabular}{lcc}
\hline \multicolumn{1}{c}{ Kinds of Error } & F & $\mathbf{~ \% ~}$ \\
\hline Inversion & 10 & 6 \\
Addition & 14 & 8.4 \\
Modification & 29 & 17.5 \\
Deviation & 40 & 24.2 \\
Omission & 72 & 43.6 \\
\hline Total & 165 & 100 \\
\hline
\end{tabular}

Kinds of Error

a. Inversion of Meaning

The first kind of translation error is inversion of meaning. In this research, the percentage of error in inversion of meaning was $6.0 \%$. The frequency of kinds of error in inversion of meaning was 10 of 165 errors.

The translation error can be classified as inversion because the Indonesian language as source language contradicts with the target language. The words "tingkat pendidikan pelacur yang sangat rendah" translated into "weaker social control", it was really contradicted because the source language talks about the level of education while in the target language talks about social control. In the next word "usia" translated into "increasing tolerance towards prostitution and infidelity", that words did not have any connection in meaning. The inversion of meaning can mislead the reader for understanding the meaning of the writing.

In the other case, in the source language, the words "deskriptif-kualitatif" translated into "descriptive-quantitative research" is a translation error with inversion of meaning. This error cannot be tolerated because it can lead the reader to be a dizzy reader because of the contradiction in the meaning from the source language into the target language. For making a good translation of a sentence, the translator should have a deep concentration. The translator can minimize the error of translation by concentrating to the sentence.

b. Addition of meaning

The second kind of translation error is addition of meaning. In this 
research, the percentage of error in addition of meaning was $8.4 \%$. The frequency was 14 of 165 errors. Two of the cases found in this research were; the first case, in the target language (English language), there is words "which has similar characteristic in class and students" while in the source language, these words are nothing. It can be classified as error with addition of meaning. In reading a writing, if the readers difficult to understand the writing, they can see the source language of a writing for getting the real meaning of the writing. The words "which has similar characteristic in class and students" can make the reader difficult to understand about the main point of the writing because the source language differs from the target language in the other words, there is an addition of meaning in the target language.

The second case, the translator put new sentences in the target language that did not exist in the source language. This case actually has a same condition with the first case but in this second case, the student made longer sentence in the target language while the meaning cannot be found in the source language. The translator broadened the meaning of the source language by adding some new words in the target language. Adding new words of writing means adding new argument to the target language and it can make the reader misunderstand about the main purpose of the writing.

\section{c. Omission of meaning}

The third kind of translation error is omission of meaning. In this research, the percentage of error in omission of meaning was $43.6 \%$. It was obtained 72 of 165 errors and be the largest of the kinds of translation error. Omission is the opposite of addition. Addition adds some words in the target language while omission omits some words in the target language or the other words; the idea in the source language does not fully transferred into the target language. The researcher found any Omission Error such us, the words "Teknik pengumpulan datanya dilakukan melalui wawancara, observasi, dan dokumentasi" were not transferred into the target language. The different words or phrase between the source and the target language mean difference in meaning. For getting a good translation, a translator should transfer the meaning of the writing without omitting some words of the source language. The Error of omission of meaning omits some meaning of writing so the translator should avoid this error of translation.

The successful translation marked by fully transferred the meaning of the writing and the failure of translation marked by the meaning not fully transferred to the target language. Error of omission of meaning is one of the markings of failure in translation. the words "Selanjutnya pada siklus III lebih meningkat lagi dengan rata-rata 18,62\% dari perolehan nilai rata-rata skor diksi 28, tipografi 19, pengimajian 28, dan tema 20" was not transferred into English as the target language. It means the translation is far from the successful translation because it did not fully transfer the meaning from the source language into the target language. The first case omitted only a part of a sentence while the second case omitted all of the sentence.

\section{d. Deviation of meaning}

The fourth kind of translation error is deviation of meaning. In this research, the percentage of error in deviation of meaning was $24.2 \%$. The frequency was 40 of 165 errors. Translation error of deviation of meaning is a vague translation. The readers get the objective of the writing easily by reading a clear reading, so the vague translation hinder the reader in getting the meaning well. In the example above, the writer did a vague translation. In the source text, the word "dapat ditingkatkan" is a passive 
form translated into active form "can improved". Without putting "be" before "improve" means that it is an active sentence an can be translated as "dapat meningkatkan" and it is a vague translation. A vague translation or translation error of deviation of meaning hinder the readers to understand the writing well.

The choosing of exact word is part of making good translation. Using the precise word can facilitate the readers to understand the writing. In the data found, the word "mengetahui" translated into "Acknowledged". In this case, the translator chose a wrong word because "Acknowledged" means "mengakui" in Indonesian language as source language; it means that the translation is a vague translation.

\section{e. Modification of meaning}

The fifth or the last kind of translation error is modification of meaning. In this research, the percentage of error in modification of meaning was $17,5 \%$. The frequency was 29 of 165 errors. Comprehending the purpose of the writing is the aim of the readers but surely they cannot comprehend the idea of writing by reading an unclear translation of writing. In this research, the student made an error of modification of meaning. The word "kondisi sosial" translated into "social, condition" by putting comma after "social' word while comma is a punctuation mark indicating a pause. For getting the clear translation, the writer should omit the comma after word "social".

\subsection{Discussion}

There have been many researches related to the kinds of translation error such as Mansyur (2006) found that the most error of translation made by the students was modification of meaning. Abstract of theses and dissertation taken from universities in Makassar have been analyzed based on the kinds of translation error namely inversion, addition, omission, diversion and modification of meaning. It was found that the most kind of translation error made by the students of universities in Makassar was omission of meaning with 72 errors $(43.6 \%)$, the second was deviation of meaning with 40 errors $(24.2 \%)$, the third was modification of meaning with 29 errors (17.5\%), the fourth was addition of meaning with 14 errors $(8.4 \%)$, and the least was inversion of meaning with 10 errors (6.0\%). In getting the clear picture, a figure of kinds of translation error was presented in figure.

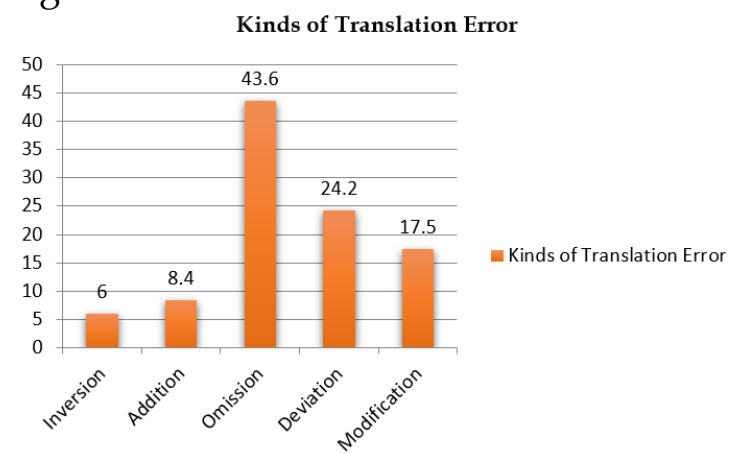

Figure 2. Kinds of translation error

The figure shows five kinds of translation errors which are dominated by omission which the least error is inversion error. The students do not generally transfer the source language into the target language with the equivalent content, meaning, and message. They should revise the target language text by comparing it with the source language text to ensure a proper rendering.

Many statements about the importance of Error Analysis especially about its connection with language learning. Brown asserts that some great effects can be gained by doing Error Analysis on classroom research (AlKhresheh. 2016).

Noss states that error is departure in the message intended to be conveyed. Errors can be found in morphological, phonological, grammatical, and even in semantic subject. All errors were made by 
the students especially in learning foreign language (Yahya, 2009). Ellis (1994) reveals the other opinion, she argues that an error can be defined as a distortion from the criteria of the target language. Pranowo (2014) has the same opinion with Ellis, he asserts that error in language is using a language by deviating some rules. This condition exactly disable to transfer the purposes of the source language to the target language well.

Corder classifies the errors into four dissimilar kind namely Addition, Omission, Selection, and Misordering. Addition refers to the addition of any grammatical item for example the students writes their task. The addition of the letter ' $\mathrm{s}$ ' in 'writes' is not required. The true sentence is "the students write their task". Omission occurs when omitting the linguistic item required in the sentence, for example the student write his task. The letter 's' is omitted from the word 'write'. The real sentence is "the student writes his task". Selection refers to the problem of using the wrong form of the word, for example they are eat mango now. That sentence does not need bare infinitive verb but it needs participle form. Misordering refers to the wrong sequence of the words in the sentence for example we swim in the pool swimming. The words pool and swimming should be reversed for creating a good order (Jabeen. 2015).

In line with Corder, Ellis explains that Addition Error is done by putting unnecessary element. Omission Error appears when the students leave a required item in a constructed sentence. Selection Error can be done by selecting an incorrect element or word. Lastly, Misordering Error which can be done by misplacing the item or putting it in the wrong place (Al-Khresheh. 2016).

Sager has another opinion about the kinds of error and his opinion covers all the opinions above. Sager divides the kinds of error into five namely Inversion (the purpose of the target language discords with the goal of source language). Addition (the view of the target language is wider than the source). Omission (the purpose or the view of the origin language is not transferred totally). Deviation (digressing the view of the root language to other idea). Modification (stating the view of the root language into an unclear chain of words). Any errors which not included in the above categories are categorized as Modification Error (Mansyur. 2006).

Focus or concentrate to the subject matter is a way to get the best result of translation. Transferring the message from the source language to the target language is the aim of translation, while the result above showed that most students did not translate the whole text from the source to the target language even, there are many sentences were not translated into target language. This happened not only because of less of focus and concentrate to the message of the source language when translating the sentence but also because of lack of competence in translation (Corder. 1974).

\section{CONCLUSION}

Based on the findings in the previous part, the researcher concluded that the students of universities in Makassar still difficult to transfer the message from Indonesian to English text. The researcher distinguishes between error and mistake: the former cannot be self-corrected because it is the yield of patchy learning and the deficiency of the learners' linguistic capability, whilst the latter is the outcome of low performance of language because of many factors such as fatigue, carelessness or lack of concentration on learning, etc. It means that the students were difficult to transfer the whole message to the target language because of the lack of competence about the target language but unfortunately, sometimes the students put new words or sentence in the target language that nothing in the source language.

\section{REFERENCES}


Basnet, S. (1991). Translation Study. Newmark, P. (1981). A Textbook of London: Routledge.

Bell, T. R. (1991). Translation and Translating. London: Oxford University.

Brislin, R. W. (1976). Translation, Application, and Research. New York: Gardner Press.

Fraenkell, J. R., \& Wallen, N. G. (1993). How to design and Evaluate research in Education. New York: Oxford University Press.

Grahaprilwana. (2009). An Analysis of Figurative Language Translation in Mark Twain's Novel Entitled Adventures of Huckleberry Finn. Published S1 Thesis. Bandung: Universitas Pendidikan Indonesia.

Haryanto. (2010). Research Methods for Language and Literature Studies. Makassar: Badan Penerbit UNM.

Larson, M. (1984). Meaning-Based Translation. New York.: University Press of America.

Mahdi, Ahmad. (2012). Students' Strategies in translating an English text into Bahasa Indonesia. Published Thesis. Bandung: UPI Bandung

Mansyur, A. (2006). The Profile of Indonesian-English Translation Made by English Department Students of Universities in Makassar. Makassar: State University of Makassar.

Mehta, N. K. (2010). English Language Teaching Through the Translation Method.

URL:http://translationjournal.net/jour nal/51mongolian.htm (Accessed 24th March 2014).

Moir, Robert, H. C. (2010). Reconsidering Backward Error Analysis for Ordinary Differential Equations. Published Thesis. London: The University of Western Ontario. Translation. New York: Prentice Hall.

Nida, E. A., \& Taber, C. A. (1982). The Theory and Practice of Translation. Leiden: E.J Brill.

Owen, R. (1998). The Translator's Handbook, 3rd Edition. London: Aslib, The association for information Management Information House.

Sekaran, Uma. (2006). Metode Penelitian Bisnis. Jakarta: Salemba Empat.

Zoltan, P., \& Hipp, H. (2005). Writing an Abstract. Writing Center Learning Guide: The University of ADELAIDE. 